OPEN ACCESS

Edited by:

Rafael De Prado,

Universidad de Córdoba, Spain

Reviewed by:

Shabir Hussain Wani

Michigan State University,

United States

Fernando José Cebola Lidon,

Faculdade de Ciências e Tecnologia da Universidade Nova de Lisboa,

Portugal

Ricardo Alcántara-de la Cruz, Deparment of Entomology, Federal

University of Viçosa, Brazil

${ }^{*}$ Correspondence:

Maxwel C. Oliveira

maxwelco@gmail.com

Specialty section

This article was submitted to Agroecology and Land Use Systems,

a section of the journal

Frontiers in Plant Science

Received: 11 October 2017

Accepted: 11 January 2018

Published: 02 February 2018

Citation:

Oliveira MC, Gaines TA, Jhala AJ and Knezevic SZ (2018) Inheritance of

Mesotrione Resistance in an Amaranthus tuberculatus (var. rudis)

Population from Nebraska, USA.

Front. Plant Sci. 9:60

doi: 10.3389/fpls.2018.00060

\section{Inheritance of Mesotrione Resistance in an Amaranthus tuberculatus (var. rudis) Population from Nebraska, USA}

\author{
Maxwel C. Oliveira ${ }^{1 *}$, Todd A. Gaines ${ }^{2}$, Amit J. Jhala ${ }^{3}$ and Stevan Z. Knezevic ${ }^{1}$ \\ ${ }^{1}$ Department of Agronomy and Horticulture, University of Nebraska-Lincoln, Concord, NE, United States, ${ }^{2}$ Department of \\ Bioagricultural Sciences and Pest Management, Colorado State University, Fort Collins, CO, United States, ${ }^{3}$ Department of \\ Agronomy and Horticulture, University of Nebraska-Lincoln, Lincoln, NE, United States
}

A population of Amaranthus tuberculatus (var. rudis) evolved resistance to 4hydroxyphenylpyruvate dioxygenase (HPPD) inhibitor herbicides (mesotrione, tembotrione, and topramezone) in Nebraska. The level of resistance was the highest to mesotrione, and the mechanism of resistance in this population is metabolism-based likely via cytochrome P450 enzymes. The increasing number of weeds resistant to herbicides warrants studies on the ecology and evolutionary factors contributing for resistance evolution, including inheritance of resistance traits. In this study, we investigated the genetic control of mesotrione resistance in an A. tuberculatus population from Nebraska, USA. Results showed that reciprocal crosses in the F1 families exhibited nuclear inheritance, which allows pollen movement carrying herbicide resistance alleles. The mode of inheritance varied from incomplete recessive to incomplete dominance depending upon the F1 family. Observed segregation patterns for the majority of the F2 and back-cross susceptible (BC/S) families did not fit to a single major gene model. Therefore, multiple genes are likely to confer metabolism-based mesotrione resistance in this A. tuberculatus population from Nebraska. The results of this study aid to understand the genetics and inheritance of a non-target-site based mesotrione resistant A. tuberculatus population from Nebraska, USA.

Keywords: waterhemp, herbicide resistance evolution, polygenic, 4-hydroxyphenylpyruvate dioxygenase, metabolism-based resistance

\section{INTRODUCTION}

Waterhemp [Amaranthus tuberculatus (var. rudis)] is a classic example of herbicide resistance evolution. A. tuberculatus is a native species of the Midwestern United States, and it has become a predominant weed in corn-soybean cropping systems (Owen, 2008; Waselkov and Olsen, 2014). The biology of $A$. tuberculatus is an important factor contributing to its adaptation in row-crop production systems. The dioecious nature of $A$. tuberculatus enforces cross-pollination and the potential for gene flow of herbicide resistance genes (Trucco et al., 2005, 2006; Sarangi et al., 2017). Moreover, a single A. tuberculatus female plant can produce over a million seeds depending on density (Hartzler et al., 2004); therefore, herbicide resistance may evolve and spread faster in A. tuberculatus than other monoecious weedy Amaranthus. A. tuberculatus is ranked among the 
worst herbicide resistant weeds (Tranel et al., 2011; Heap, 2014). As of 2017, populations of A. tuberculatus have evolved resistance to six herbicide sites-of-action (SOA) in the United States (Heap, 2017).

Herbicides inhibiting 4-hydroxyphenylpyruvate dioxygenase (HPPD) represent the latest introduced SOA for weed control in corn, commercialized in the late 1980's (Mitchell et al., 2001; Duke, 2012). Mesotrione, an HPPD-inhibitor herbicide, was introduced as an effective preemergence (PRE) and postemergence (POST) herbicide for controlling various broadleaf weeds, including A. tuberculatus (Mitchell et al., 2001; Sutton et al., 2002). However, resistance to mesotrione evolved recently (Hausman et al., 2011; McMullan and Green, 2011), and it is increasing across the north-central United States (Schultz et al., 2015). The persistence and adaptation of HPPD-inhibitor herbicide-resistant $A$. tuberculatus populations to croppingsystems is a concern. There will be a potential increased use of these herbicides by the use of transgenic HPPD-inhibitorresistant crops in the United States. Therefore, tactics are needed to minimize the evolution of resistance to this herbicide group.

The mechanism of herbicide resistance discovered in $A$. tuberculatus varies according to the herbicide SOA, which can be either target site resistance (TSR) or non-target site resistance (NTSR). Target-site amino acid substitutions, codon deletion, and gene amplification are the major mechanisms of TSR (Patzoldt and Tranel, 2007; Thinglum et al., 2011; Lorentz et al., 2014; Chatham et al., 2015), which are often caused by a dominant gene in a single locus (Délye et al., 2013). In contrast, NTSR includes mechanisms that are not TSR, frequently resulting from multiple genes conferring reduced herbicide penetration, herbicide differential translocation, and enhanced herbicide metabolism (Powles and Yu, 2010; Délye, 2013; Délye et al., 2013). Enhanced metabolism (NTSR) is the only reported mechanism of mesotrione resistance in $A$. tuberculatus (Ma et al., 2013; Kaundun et al., 2017).

A population of $A$. tuberculatus (hereafter referred as $\mathrm{R}$ ) has evolved resistance to POST-applied HPPD-inhibitor herbicides (mesotrione, tembotrione, and topramezone) in a corn/soybean production system in northeast Nebraska (Oliveira et al., 2017a). Mesotrione detoxification to 4-hydroxymesotrione has been confirmed as the mechanism of resistance in this population (Kaundun et al., 2017). Further research characterized the role of cytochrome P450 enzymes in this R population, as malathion (a cytochrome P450 inhibitor) did not synergize mesotrione (Oliveira et al., 2017b). This result is different from what was previously reported in a different mesotrione resistant A. tuberculatus population from Illinois, in which malathion synergized mesotrione (Ma et al., 2013). It is likely that different P450 enzymes are endowing mesotrione resistance in different A. tuberculatus populations. Therefore, empirical studies are needed to understand the eco-evolutionary dynamics causing weed evolution (Neve et al., 2009, 2014). For example, inheritance studies can improve our knowledge of the genetic structure of weed populations under herbicide selection and aid to create appropriate herbicide resistance simulation models (Neve et al., 2014; Renton et al., 2014; Menalled et al., 2016).
Inheritance of herbicide alleles contributing to pesticide (e.g., herbicide) resistance can vary with different genetic backgrounds and dose environment (Ffrench-Constant et al., 2004; Neve et al., 2014). Thus, the objective of this study was to determine the mode of inheritance and number of alleles controlling mesotrione resistance in the $\mathrm{R}$ population from Nebraska with two experiments: (1) dose-response studies with parental [mesotrione R and susceptible (S)] and F1 families generated from the $\mathrm{S} \times \mathrm{R}$ cross; and (2) segregation studies in pseudo-F2 and back cross (BC) families with low, recommended, and high mesotrione dose.

\section{METHODS}

\section{Plant Material and Growth Condition}

Two A. tuberculatus were the originating populations in this study. This species is an obligate outcrosser so inbred lines could not be developed to establish parents for the inheritance studies. The seeds of the R population were collected in 2014 from a field in Platte County, NE, where mesotrione resistance was confirmed (Oliveira et al., 2017a). The S population seeds were collected from Dixon County, NE; this population was known to have high sensitivity to mesotrione. For both populations, seeds were collected from at least 20 plants. The seeds were cleaned and stored separately (R and S populations) at $5 \mathrm{C}$ until used in the greenhouse study in 2015 and 2016 at the University of NebraskaLincoln. Seeds were planted in $1200 \mathrm{~cm}^{3}$ plastic pots for pairwise crosses containing peat:soil:sand:vermiculite (4:2:2:2) potting mix. In addition, seeds were planted in $164 \mathrm{~cm}^{3}$ conetainers (Ray Leach "Cone-tainer" SC10 ${ }^{\circledR}$, Stuewe and Sons Inc, Tangent, OR, USA) for dose-response and segregation analysis with the same potting mix described. Plants were supplied with adequate water and kept under greenhouse conditions at $28 / 20 \mathrm{C}$ day/night temperature with $80 \%$ relative humidity. In addition, twice per week, plants were fertilized with $3 \mathrm{mg}$ of NPK (20-10-20 Peters ${ }^{\circledR}$ Professional, JR Peters Inc., Allentown, PA, USA) for each $100 \mathrm{~cm}^{3}$ of the potting mix until plants were $8-10 \mathrm{~cm}$ tall. Artificial lighting was provided using metal halide lamps $\left(600-\mu \mathrm{mol}\right.$ photons $\left.\mathrm{m}^{-2} \mathrm{~s}^{-1}\right)$ to ensure a $15-\mathrm{h}$ photoperiod.

\section{Generations of F1, Pseudo-F2, and Back-Cross Families}

The $\mathrm{R}$ population was grown from seeds in a greenhouse and selected with a POST application of the recommended rate of $105 \mathrm{~g}$ ai ha ${ }^{-1}$ of mesotrione (Callisto ${ }^{\circledR}$, Syngenta Crop Protection, Research Triangle Park, NC, USA) when R seedlings were $10-15 \mathrm{~cm}$ tall. The recommended mesotrione rate caused low injury $(<30 \%)$ on $\mathrm{R}$ plants. Therefore, the $\mathrm{R}$ plants were kept for individual pairwise crosses with the $S$ plants. Single $S$ and $\mathrm{R}$ plants growing in pots were paired according to floral synchrony and enclosed with pollination bags (100 by 185 $\mathrm{cm})$ to exclude external pollen. Male plant inflorescences were gently shaken in the morning during pollination period $(\sim 3$ weeks) to ensure cross-fertilization between $\mathrm{S}$ and $\mathrm{R}$ individuals. At maturity, seeds were collected from each female plant, 
cleaned, and bagged separately, then designated as F1 families (Figure 1).

The F1 families were derived from 20 parental crosses. Four F1 families were advanced to the next generation of crosses (Table S1), including three $\mathrm{S} \times \mathrm{R}$ and one $\mathrm{R} \times \mathrm{S}$ (female $\times$ male). The F1 plants were termed RS/F1-5, SR/F1-8, SR/F1-9, and SR/F1-13 (Table S1). The R parent of the SR/F1-13 family was derived from an $\mathrm{R} \times \mathrm{R}$ cross of the $\mathrm{R}$ population seeds, and the $\mathrm{R}$ $\times R$ cross was performed under greenhouse conditions, similarly as described for the $\mathrm{S} \times \mathrm{R}$ cross. The remaining $\mathrm{F} 1$ families were derived from field collected $\mathrm{R}$ and $\mathrm{S}$ seeds. The F1 plants were treated with $105 \mathrm{~g}$ ai ha ${ }^{-1}$ of mesotrione when plants were 10 to $15 \mathrm{~cm}$ tall. The $\mathrm{F} 1$ plants survived with variable mesotrione injury (data not shown) confirming that they were crosses between $\mathrm{R}$ and $\mathrm{S}$. A. tuberculatus is dioecious, preventing F1 self-pollination to produce true F2 plants (Figure 1). Therefore, the F1 family SR/F1-9 and SR/F1-13 individuals were separately cross-pollinated using the procedures described above to make pseudo-F2 plants (hereinafter referred as F2). The F2 plants were designed F2-9 (from SR/F1-9) and F2-13 (from SR/F113). In addition, F1 male plants were also allowed to pollinate the parental susceptible female plants (S) to produce backcross susceptible (BC/S) families (Figure 1). Three BC/S families were made and designed BC-8/S (from SR/F1-8), BC-9/S (from SR/F19), and BC-13/S (from SR/F1-13; Table S1).

\section{Dose-Response of Mesotrione in F1 Families and Parental Population}

The greenhouse experiments were set in completely randomized design with four replications and repeated twice in 2016 at the University of Nebraska-Lincoln. Mesotrione dose-response studies were conducted separately with R and S (parent); and F1 families, including RS/F1-5, SR/F1-9, and SR/F1-13.

The mesotrione dose was $0,0.125 \times, 0.25 \times, 0.5 \times, 1 \times, 2 \times$, $4 \times, 8 \times, 16 \times$, where $1 \times$ represents $105 \mathrm{~g}$ ai ha ${ }^{-1}$ (labeled use rate of mesotrione). Mesotrione was mixed with $1 \%(\mathrm{v} / \mathrm{v})$ crop oil concentrate (Agri-Dex ${ }^{\circledR}$, Helena Chemical Co, Collierville, TN, USA) and $20.5 \mathrm{~g} \mathrm{~L}^{-1}$ of ammonium sulfate (DSM Chemicals North America Inc., Augusta, GA, USA). Herbicide treatments were applied with a single tip chamber sprayer (DeVries Manufacturing Corp, Hollandale, MN, USA) fitted with an 8001 E nozzle (Spraying Systems Co., North Avenue, Wheaton, IL 60139), calibrated to deliver $140 \mathrm{~L} \mathrm{ha}^{-1}$ spray volume at $210 \mathrm{kPa}$ at a speed of $3.7 \mathrm{~km} \mathrm{~h}^{-1}$. Control was assessed visually $21 \mathrm{~d}$ after treatment (DAT) using a scale of 0 to $100 \%$ (where 0 indicates no injury and 100 indicates plant death). Control ratings were based on symptoms such as bleaching, necrosis, and stunting of plants compared to non-treated control plants. Aboveground biomass was harvested at 21 DAT from each experimental unit and ovendried at $65 \mathrm{C}$ until reaching constant weight before the weight of biomass $\left(\mathrm{g} \mathrm{plant}^{-1}\right)$ was recorded.

The effective mesotrione doses needed to control and reduce biomass by $50 \%\left(\mathrm{ED}_{50}\right)$ and $90 \%\left(\mathrm{ED}_{90}\right)$ for the parental and $\mathrm{F} 1$ families were determined using the three-parameter log-logistic curve of the drc package of the R statistical software (Knezevic et al., 2007).

$$
Y=d / 1+\exp \{b[\log (x)-\log (e)]\}
$$

In this model, $\mathrm{Y}$ is the control (\%) or biomass reduction ( $\mathrm{g}$ plant $\left.{ }^{-1}\right), d$ is the upper limit, and $e$ represents the $\mathrm{ED}_{50}$ value relative to $d$. The parameter $b$ is the relative slope around the parameter $e$, and $x$ is the mesotrione dose in $\mathrm{g}_{\text {ai ha }}{ }^{-1}$.

\section{Parental cross

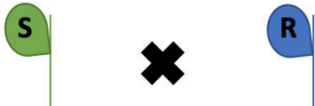 \\ Susceptible (S) Resistant (R)}

Generated F1 family
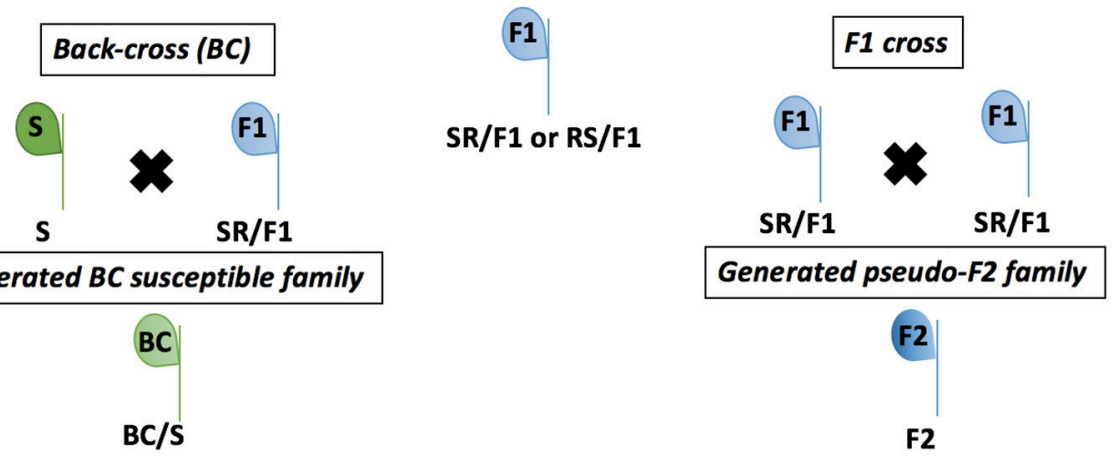

FIGURE 1 | Crosses of Amaranthus tuberculatus populations (R and S) to generate F1, F2, and BC/S families conducted in greenhouse at the University of Nebraska-Lincoln. 
The resistance level was calculated by dividing the effective dose for providing $50 \%$ control or $50 \%$ biomass reduction $\left(\mathrm{ED}_{50}\right)$ of the $\mathrm{R}$ or $\mathrm{F} 1$ populations by the $\mathrm{ED}_{50}$ of the $\mathrm{S}$ population. The resistance level indices for the respective $E_{50}$ between the $R$ or F1, and the S were compared using the EDcomp function of package drc in R software (Ritz and Streibig, 2005). The EDcomp function compares the ratio of $\mathrm{ED}_{50}$ using t-statistics, where $P$-value $<0.05$ indicates that herbicide $\mathrm{ED}_{50}$ values are different between the $\mathrm{R}$ or $\mathrm{F} 1$ and the $\mathrm{S}$.

The degree of dominance $(D)$ was calculated following the formula

$$
D=\left[\left(2 X_{2}-X_{1}-X_{3}\right) /\left(X_{1}-X_{3}\right)\right]
$$

Where $D$ is the degree of dominance and $X_{1}, X_{2}$, and $X_{3}$ are the $\log \left(\mathrm{ED}_{50}\right)$ of $\mathrm{R}, \mathrm{F} 1$, and $\mathrm{S}$ population, respectively. When
$D=0$, the $\mathrm{F} 1$ has a resistance level that is the mean of the $\mathrm{R}$ and $S$ (additive). When $D=1$ there is an indication of complete dominance, $0<D<1$ supports the model of incomplete dominance, $-1<D<0$ of incomplete recessive, and $D=-1$ of complete recessive (Stone, 1968).

\section{Mesotrione Segregation in Amaranthus tuberculatus F2 and BC/S Families}

The R and S parent, SR/F1 (SR/F1-8, SR/F1-9, and SR/F1-13), F2 (F2-9 and F2-13) and BC/S (BC-8/S, BC-9/S, and BC-13/S) families were treated with three mesotrione doses attempting to discriminate $\mathrm{S}$ from $\mathrm{R}$ plants. These doses were 26, 105, and $420 \mathrm{~g}$ ai ha ${ }^{-1}$, which represent $0.25 \times, 1 \times$, and $4 \times$ the recommended rate, respectively. The $0.25 \times$ dose was chosen to assess segregation at a below-label dose. The $1 \times$ dose was chosen to evaluate segregation at recommended label dose at which
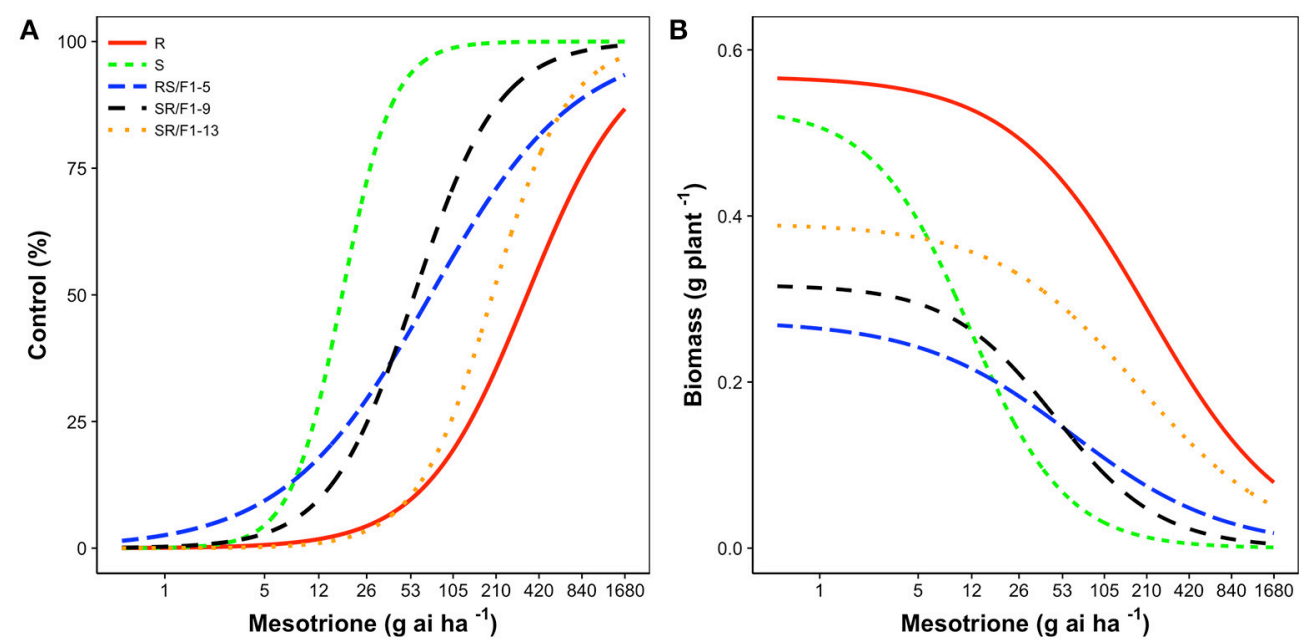

FIGURE 2 | Mesotrione dose-response on (A) Control (\%) and (B) Biomass (g plant ${ }^{-1}$ ) of Amaranthus tuberculatus families (R and S parent populations; and F1 families, RS/F1-5, SR/F1-9, and SR/F1-13) conducted in greenhouse at the University of Nebraska-Lincoln.

TABLE 1 | Estimated parameters ( $b, d$, and e) and effective dose to control 90\% (EDgo) of Amaranthus tuberculatus (R and S parent populations; and F1 families, RS/F1-5, SR/F1-9, and SR/F1-13) conducted in greenhouse at the University of Nebraska-Lincoln.

\begin{tabular}{|c|c|c|c|c|c|c|}
\hline \multirow[t]{2}{*}{ Population ${ }^{a}$} & \multicolumn{3}{|c|}{ Parameter ${ }^{b}$} & \multirow[t]{2}{*}{$E_{90}( \pm S E)$} & \multirow[t]{2}{*}{$P$-value ${ }^{c}$} & \multirow[t]{2}{*}{ Resistance level ${ }^{\circ}$} \\
\hline & $b( \pm S E)$ & $d( \pm \mathrm{SE})$ & e $\left(E D_{50}\right)( \pm S E)$ & & & \\
\hline \multicolumn{7}{|c|}{$\mathrm{g}$ ai ha $\mathrm{h}^{-1}$} \\
\hline S & $-2.4(0.2)$ & 100 & $18(1)$ & $43(4)$ & - & - \\
\hline $\mathrm{R}$ & $-1.2(0.1)$ & 100 & 348 (19) & 2199 (257) & 0.00 & 19 \\
\hline $\mathrm{RS} / \mathrm{F} 1-5$ & $-0.8(0.0)$ & 100 & $73(4)$ & $981(143)$ & 0.00 & 4 \\
\hline $\mathrm{SR} / \mathrm{F} 1-9$ & $-1.5(0.1)$ & 100 & $56(2)$ & $255(27)$ & 0.00 & 3 \\
\hline SR/F1-13 & $-1.6(0.1)$ & 100 & $198(9)$ & $759(80)$ & 0.00 & 11 \\
\hline
\end{tabular}

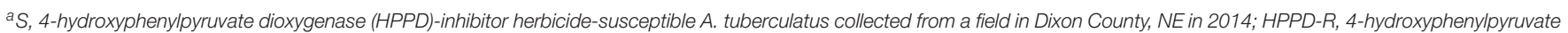

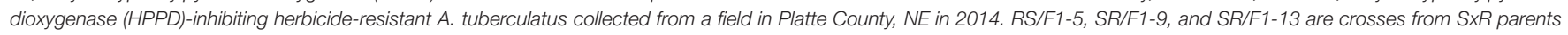
made under greenhouses conditions.

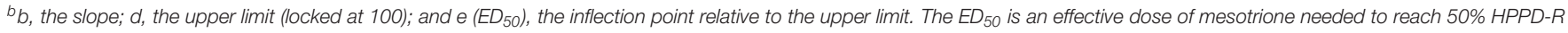
control. SE, standard error.

${ }^{c} R$ and $F 1$ families vs. S population t-statistics comparison of e (ED 50$), P$-value $>0.05$ means non-significant difference between treatments.

${ }^{d}$ Resistance level was calculated dividing e $\left(E D_{50}\right)$ value of $R$ and $F 1$ families by $S$ population. 
plants are selected under field conditions. The higher dose $(4 \times)$ was selected to likely allow mesotrione resistance segregation to occur with minimal interference of minor resistance loci (Busi et al., 2014). There were two runs (repetitions in time) of this experiment for each mesotrione dose, and each run included $\mathrm{BC} / \mathrm{S}$ and F2 populations represented by 29 to 98 , and 56 to 98 plants, respectively. In addition, parent ( $\mathrm{R}$ and $\mathrm{S}$ ) populations were represented by 8 to 17 plants, and F1 populations were represented by 8 to 24 plants. A total of 2,908 A. tuberculatus plants were screened with mesotrione in this study. Herbicide application was the same as described above in dose-response studies. At 21 DAT, all populations were visually evaluated and assessed as dead or alive. Alive plants were separated into different injury level groups, including low $(<40 \%)$, medium (41 to $79 \%$ ), high ( 80 to $98 \%$ ), and dead ( $>98 \%$; Figure S1). Plant aboveground biomass was harvested, oven-dried until constant weight, and biomass (g plant ${ }^{-1}$ ) was recorded. The plant biomass and injury level for parental, SR/F1, F2, and BC/S families were represented in violin plots with a rotated kernel density plot using package ggplot2 in R statistical software (Wickham, 2009).

The experimental null hypothesis was that mesotrione resistance segregates as controlled by a single major gene (one locus). The segregation analysis in $\mathrm{F} 2$ and $\mathrm{BC} / \mathrm{S}$ families was based on the observed survival ratio (alive/total treated plants) compared to expected survival assuming one gene locus segregation (Table S2). For the F2 and BC/S families, the expected number of surviving plants was described by the following equations (Tabashnik, 1991; Busi et al., 2013; Han et al., 2014):

F2: One gene locus model (1R:2F1:1S),

Exp. $\mathrm{F} 2=0.25 \times$ Obs $R+0.5 \times$ Obs F $1+0.25 \times$ Obs $S$

BC/S: One gene locus model (1F1:1S),

$$
\text { Exp. } \mathrm{BC} / \mathrm{S}=0.5 \times(\mathrm{F} 1+\mathrm{S})
$$

where $\mathrm{R}, \mathrm{F} 1$, and $\mathrm{S}$ are the number of observed surviving plants of the $\mathrm{R}, \mathrm{F} 1$, and $\mathrm{S}$ families at each mesotrione dose $\left(26,105\right.$, and $420 \mathrm{~g}$ ai ha $\left.{ }^{-1}\right)$. Thus, for each dose, the expected number of survivors for $\mathrm{F} 2$ and $\mathrm{BC} / \mathrm{S}$ populations was calculated with the total number of treated plants multiplied by the theoretical one locus segregation ratio for $\mathrm{F} 2$ and $\mathrm{BC} / \mathrm{S}$ families.

A chi-square goodness-of-fit test $\left(\chi^{2}\right)$ was used to compare the observed and expected plant survival based on a one locus segregation model. The $P$-values were obtained to indicate the probability in rejecting the null hypothesis for $\mathrm{F} 2$ and $\mathrm{BC} / \mathrm{S}$ families at one locus segragation. For example, for one locus segregation, the null hypothesis $\left(\mathrm{H}_{0}\right)$ is that the $\mathrm{BC}$ segregates as

TABLE 3 | Degree of dominance based on logarithm of parameter e $\left(E D_{50}\right)$ control and biomass (g plant ${ }^{-1}$ ) of Amaranthus tuberculatus ( $\mathrm{R}$ and $\mathrm{S}$ parent populations; and F1 families, RS/F1-5, SR/F1-9, and SR/F1-13) conducted in greenhouse at the University of Nebraska-Lincoln.

\begin{tabular}{|c|c|c|c|c|}
\hline Population ${ }^{a}$ & Control & $\begin{array}{c}\text { Degree of } \\
\text { dominance }^{b}\end{array}$ & Biomass & $\begin{array}{c}\text { Degree of } \\
\text { dominance }^{b}\end{array}$ \\
\hline & $\log \left(E D_{50}\right)$ & & $\log \left(E D_{50}\right)$ & \\
\hline $\mathrm{R}$ & 5.85 & - & 5.37 & - \\
\hline S & 2.86 & - & 2.45 & - \\
\hline RS/F1-5 & 4.29 & -0.04 & 4.18 & 0.14 \\
\hline SR/F1-9 & 4.03 & -0.22 & 3.84 & -0.05 \\
\hline SR/F1-13 & 5.29 & 0.62 & 5.21 & 0.88 \\
\hline F1-pooled & 4.53 & 0.11 & 4.39 & 0.32 \\
\hline
\end{tabular}

as, 4-hydroxyphenylpyruvate dioxygenase (HPPD)-inhibitor herbicide-susceptible A. tuberculatus collected from a field in Dixon County, NE in 2014; HPPD-R, 4hydroxyphenylpyruvate dioxygenase (HPPD)-inhibiting herbicide-resistant $A$. tuberculatus collected from a field in Platte County, NE in 2014. RS/F1-5, SR/F1-9, and SR/F1-13 are crosses from SXR parents made under greenhouses conditions.

${ }^{b}$ Degree of dominance was calculated using the formula $D=\left[\left(2 X_{2}-X_{1}-X_{3}\right) /\left(X_{1}-X_{3}\right)\right]$, where $X 1, X_{2}$, and $X_{3}$ represent the e $\left(E D_{50}\right)$ values of $R, S$, and respective $F 1$ family.

TABLE 2 | Estimated parameters (b, d, and e) and effective dose to reduce biomass (g plant ${ }^{-1}$ ) $90 \%$ (EDgo) of Amaranthus tuberculatus (R and $\mathrm{S}$ parent populations; and F1 families, RS/F1-5, SR/F1-9, and SR/F1-13) conducted in greenhouse at the University of Nebraska-Lincoln.

\begin{tabular}{|c|c|c|c|c|c|c|}
\hline \multirow[t]{2}{*}{ Population $^{a}$} & \multicolumn{3}{|c|}{ Parameter ${ }^{\mathbf{b}}$} & \multirow[t]{2}{*}{$\mathrm{ED}_{90}( \pm \mathrm{SE})$} & \multirow[t]{2}{*}{$P$-value ${ }^{c}$} & \multirow[t]{2}{*}{ Resistance leveld } \\
\hline & $b$ ( \pm SE) & $d$ ( \pm SE) & e $\left(E D_{50}\right)( \pm S E)$ & & & \\
\hline & \multicolumn{2}{|c|}{ Biomass (g plant ${ }^{-1}$ ) } & \multicolumn{2}{|c|}{ g ai ha-1 } & & \\
\hline S & $1.3(0.2)$ & $0.5(0.0)$ & $12(1)$ & $66(12)$ & - & - \\
\hline $\mathrm{R}$ & $0.9(0.1)$ & $0.6(0.0)$ & $216(23)$ & 2665 (408) & 0.0 & 18 \\
\hline RS/F1-5 & $0.8(0.1)$ & $0.3(0.0)$ & $62(15)$ & $956(340)$ & 0.0 & 5 \\
\hline $\mathrm{SR} / \mathrm{F} 1-9$ & $1.2(0.2)$ & $0.3(0.0)$ & $47(7)$ & $314(86)$ & 0.0 & 4 \\
\hline SR/F1-13 & $1.0(0.1)$ & $0.4(0.0)$ & $183(31)$ & 2354 (686) & 0.0 & 15 \\
\hline
\end{tabular}

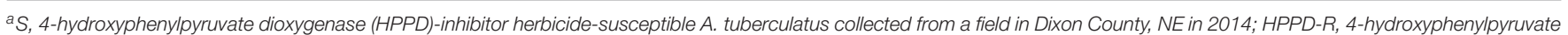

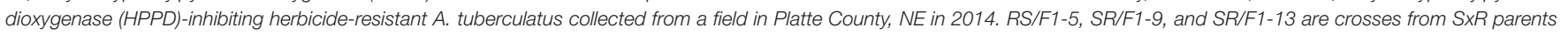
made under greenhouses conditions.

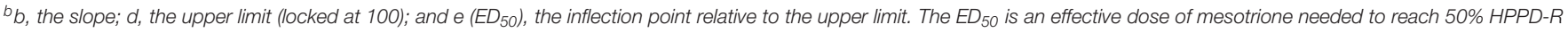
control. SE, standard error.

${ }^{c} R$ and $F 1$ families vs. S population t-statistics comparison of e $\left(E D_{50}\right)$, P-value $>0.05$ means non-significant difference between treatments.

${ }^{d}$ Resistance level was calculated dividing $e\left(E D_{50}\right)$ value of $R$ and $F 1$ families by $S$ population. 
0.5F1:0.5S. The significant level is $\alpha=0.05$ and if $P$-value $<0.05$, the null hypothesis is rejected.

\section{RESULTS}

\section{Mode of Inheritance of Mesotrione Resistance}

The $\mathrm{R}$ population displayed a high level of resistance whereas $S$ was susceptible (Figures 2A,B). The level of resistance of $R$ compared to $\mathrm{S}$ was 19 -fold based on $\mathrm{ED}_{50}$ values (Table 1). The generated F1 families provided an intermediate and relatively lower level of resistance (3-4-fold) based on $\mathrm{ED}_{50}$ values, except the SR/F1-13 family (11-fold). The biomass (g plant ${ }^{-1}$ ) of parental and F1 families corroborated with visual control, resulting in similar $\mathrm{ED}_{50}, \mathrm{ED}_{90}$, and resistance levels (Table 2).

The F1 families expressed a variable degree of dominance (D). For example, based on control, the degree of dominance of SR/F1-13 family was 0.62 (Table 3 ). In contrast, the SR/F19 family had a negative degree of dominance $(D=-0.22)$. The RS/F1-5 family had a degree of dominance close to zero $(D=-0.04)$. The pooled-F1 family resulted in $D=0.11$. Similar degree of dominance trend was also observed with plant response to mesotrione based on biomass $\left(\mathrm{g} \mathrm{plant}^{-1}\right.$ ) of the F1 families (Table 3).

\section{Mesotrione Segregation in Amaranthus tuberculatus F2 and BC/S Families}

The segregation at below-label mesotrione dose $\left(26 \mathrm{~g}_{\text {ai }} \mathrm{ha}^{-1}\right)$ resulted in $77 \%$ survival of S plants when averaging both runs, and survived $S$ plants showed high injury ( $>80 \%$; Figure $2 \mathrm{~A}$ ). In addition, the $26 \mathrm{~g}$ ai ha ${ }^{-1}$ resulted in high survival rate $(\geq 87 \%)$ of the SR/F1, F2, and BC/S families across runs. Therefore, this dose was not the best to describe a segregation analysis for this $\mathrm{R}$ population. Nonetheless, a single major gene model would not fit $(P$-value $<0.05)$ the majority of F2 and BC/S families (Table 4).

The recommended (105g ai ha ${ }^{-1}$; Table 5) and a high mesotrione rate $\left(420 \mathrm{~g}_{\text {ai ha }}{ }^{-1}\right.$; Table 6 ) effectively distinguished $\mathrm{R}$ and $\mathrm{S}$ plant survival. At these two rates, $\mathrm{R}$ plants survived with low injury $(<40 \%)$, and S plants died (Figures 3C,E). However, F1 family survival and level of injury at 105 and $420 \mathrm{~g}$ ai ha ${ }^{-1}$ varied within families (Figures $3 D, F$ ). At mesotrione rate of $105 \mathrm{~g}$ ai ha ${ }^{-1}$, segregation in each family deviated from

TABLE 4 | Phenotypic resistance segregation observed in two pseudo-F2 (F2) and three back-cross susceptible (BC/S) families at below-label mesotrione dose $\left(26 \mathrm{~g}_{\text {ai ha }}{ }^{-1}\right)$.

\begin{tabular}{|c|c|c|c|c|c|c|c|c|}
\hline Run & Dose $(g$ ai ha-1) & Familya & Plants treated & Survivors (observed) & Survival ratio & Survivors (expected) & $x^{2}$ & $P$-value \\
\hline \multirow[t]{12}{*}{1} & 26 & $\mathrm{R}$ & 10 & 10 & 1.00 & & & \\
\hline & & $S$ & 8 & 6 & 0.75 & & & \\
\hline & & $\mathrm{SR} / \mathrm{F} 1-8$ & 13 & 13 & 1.00 & & & \\
\hline & & SR/F1-9 & 9 & 9 & 1.00 & & & \\
\hline & & $\mathrm{SR} / \mathrm{F} 1-13$ & 8 & 8 & 1.00 & & & \\
\hline & & \multicolumn{3}{|c|}{ F2 segregation } & & \multicolumn{2}{|l|}{ 1R:2F1:1S } & \\
\hline & & F2-9 & 75 & 65 & 0.87 & 70.3 & 6.4 & 0.01 \\
\hline & & F2-13 & 98 & 98 & 1.00 & 91.8 & 6.6 & 0.01 \\
\hline & & \multicolumn{2}{|c|}{$\mathrm{BC} / \mathrm{S}$ segregation } & & & $1 F 1: 1 S$ & & \\
\hline & & $\mathrm{BC}-8$ & 93 & 93 & 1.00 & 81.3 & 13.4 & 0.00 \\
\hline & & BC-9 & 94 & 94 & 1.00 & 82.2 & 13.4 & 0.00 \\
\hline & & BC-13 & 60 & 57 & 0.95 & 52.5 & 3.1 & 0.07 \\
\hline \multirow[t]{12}{*}{2} & 26 & $\mathrm{R}$ & 16 & 16 & 1.00 & & & \\
\hline & & S & 14 & 11 & 0.78 & & & \\
\hline & & $\mathrm{SR} / \mathrm{F} 1-8$ & 24 & 24 & 1.00 & & & \\
\hline & & SR/F1-9 & 14 & 14 & 1.00 & & & \\
\hline & & SR/F1-13 & 24 & 24 & 1.00 & & & \\
\hline & & \multicolumn{2}{|c|}{ F2 segregation } & & & 1R:2F1:1S & & \\
\hline & & $\mathrm{F} 2-9$ & 97 & 97 & 1.00 & 91.8 & 5.5 & 0.02 \\
\hline & & F2-13 & 98 & 98 & 1.00 & 92.7 & 1.8 & 0.02 \\
\hline & & \multicolumn{2}{|c|}{$\mathrm{BC} / \mathrm{S}$ segregation } & & & 1F1:1S & & \\
\hline & & $\mathrm{BC}-8 / \mathrm{S}$ & 29 & 27 & 0.97 & 25.9 & 0.8 & 0.38 \\
\hline & & BC-9/S & 95 & 95 & 1.00 & 84.8 & 11.4 & 0.00 \\
\hline & & BC-13/S & 49 & 48 & 0.98 & 43.7 & 5.9 & 0.04 \\
\hline
\end{tabular}

Chi-square $\left(\mathrm{x}^{2}\right)$ analysis for expected plant survival assuming control for mesotrione resistance by a single major gene.

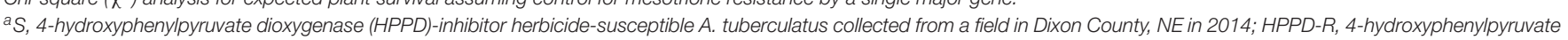

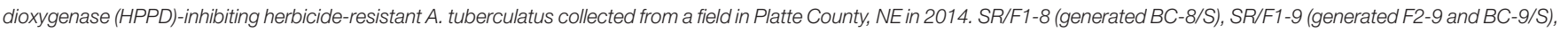
and SR/F1-13 (generated F2-13 and BC-13/S) are crosses originated from SxR parents made under greenhouses conditions. 
TABLE 5 | Phenotypic resistance segregation observed in two pseudo-F2 and three back-cross susceptible (BC/S) families at recommended label mesotrione dose $(105 \mathrm{~g}$ ai ha-1).

\begin{tabular}{|c|c|c|c|c|c|c|c|c|}
\hline Run & Dose $(g$ ai ha-1) & Family $^{a}$ & Plants treated & Survivors (observed) & Survival ratio & Survivors (expected) & $x^{2}$ & $P$-value \\
\hline \multirow[t]{12}{*}{1} & 105 & $\mathrm{R}$ & 8 & 8 & 1 & & & \\
\hline & & S & 8 & 0 & 0 & & & \\
\hline & & SR/F1-8 & 24 & 19 & 0.79 & & & \\
\hline & & SR/F1-9 & 14 & 14 & 1 & & & \\
\hline & & $\mathrm{SR} / \mathrm{F} 1-13$ & 13 & 13 & 1 & & & \\
\hline & & \multicolumn{3}{|c|}{ F2 segregation } & & \multicolumn{2}{|l|}{ 1R:2F1:1S } & \\
\hline & & F2-9 & 96 & 80 & 0.83 & 72.0 & 10.6 & 0.00 \\
\hline & & F2-13 & 98 & 87 & 0.89 & 73.5 & 9.9 & 0.00 \\
\hline & & \multicolumn{2}{|c|}{ BC/S segregation } & & & 1F1:1S & & \\
\hline & & BC-8/S & 96 & 85 & 0.89 & 37.9 & 96.7 & 0.00 \\
\hline & & BC-9/S & 96 & 90 & 0.94 & 48.0 & 73.5 & 0.00 \\
\hline & & BC-13/S & 49 & 40 & 0.82 & 24.5 & 19.6 & 0.00 \\
\hline \multirow[t]{12}{*}{2} & 105 & $\mathrm{R}$ & 17 & 17 & 1 & & & \\
\hline & & $S$ & 13 & 0 & 0 & & & \\
\hline & & SR/F1-8 & 24 & 13 & 0.55 & & & \\
\hline & & SR/F1-9 & 10 & 10 & 1 & & & \\
\hline & & SR/F1-13 & 24 & 23 & 0.96 & & & \\
\hline & & \multicolumn{3}{|c|}{ F2 segregation } & & 1R:2F1:1S & & \\
\hline & & F2-9 & 88 & 85 & 0.97 & 66.0 & 21.9 & 0.00 \\
\hline & & $F 2-13$ & 95 & 91 & 0.96 & 69.3 & 25.1 & 0.00 \\
\hline & & \multicolumn{2}{|c|}{$\mathrm{BC} / \mathrm{S}$ segregation } & & & $1 \mathrm{~F} 1: 1 \mathrm{~S}$ & & \\
\hline & & BC-8/S & 66 & 59 & 0.89 & 17.8 & 130.6 & 0.00 \\
\hline & & BC-9/S & 95 & 94 & 0.99 & 47.5 & 91.0 & 0.00 \\
\hline & & BC-13/S & 49 & 33 & 0.67 & 23.5 & 7.4 & 0.00 \\
\hline
\end{tabular}

Chi-square $\left(\mathrm{x}^{2}\right)$ analysis for expected plant survival assuming control for mesotrione resistance by a single major gene.

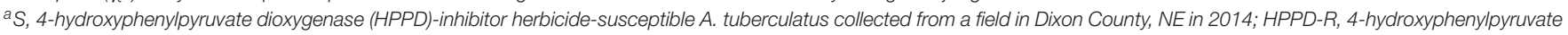

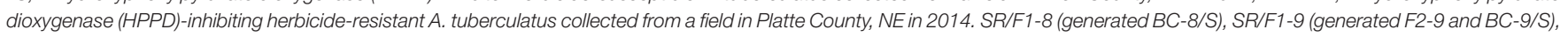
and SR/F1-13 (generated F2-13 and BC-13/S) are crosses originated from SxR parents made under greenhouses conditions.

the corrected 1R:2F1:S $\left(\mathrm{F}_{2}\right)$ and $1 \mathrm{~F} 1: 1 \mathrm{~S}(\mathrm{BC})$ ratios expected for one major gene in the two experimental runs (Table 5). Two and three loci segregation model tested fitted for most of $\mathrm{F} 2$ and $\mathrm{BC} / \mathrm{S}$, families (data not shown). For $420 \mathrm{~g}$ ai $\mathrm{ha}^{-1}$, only F2-13 (first run) and BC-8/S (second run) families did not deviate from the expected one major locus (Table 6). However, BC-8/S (first and second run), F2-13 (second run), and BC-13/S (first run) also did not deviate from two and three loci segregation (data not shown). In general, at 105 and $420 \mathrm{~g}$ ai ha ${ }^{-1}$ doses, the plant mortality was variable but higher than expected.

The plant biomass (g) and injury levels (\%) of the segregation analysis at different mesotrione doses on $A$. tuberculatus families was illustrated with combined (Figures 3A,C,E) or separated (Figures 3B,D,F) violin plots. The plant biomass of the generated families overlapped the $\mathrm{R}$ and $\mathrm{S}$ parent phenotypic ranges. The violin plots showed either continuous or bell-shaped distribution of biomass ( $\mathrm{g}$ ) across families and mesotrione rates (Figures 3A-F). For example, at $105 \mathrm{~g}^{\text {ai }} \mathrm{ha}^{-1}$ of mesotrione, the F2-9 family showed a majority of plants with low injury and highly variable biomass (Figure 3D). The F2-13 family had a medium to high injury with relatively low uniform biomass.
Nonetheless, the F2 families resulted in high plant survival (Table 5). In contrast, the BC/S families resulted in a uniform relatively low biomass across families and mesotrione doses (Figures 3B,D,F). In addition, the shape of the phenotype was more continuous and thinner as the mesotrione dose increased (Figures 3A-F).

\section{DISCUSSION}

The individual plants representing the $\mathrm{R}$ population have been under continual selection pressure for mesotrione resistance, but they have not been through inbreeding that would increase homozygosity. The F1 families showed a lack of dominance or recessivity (Table 3), and the degree of dominance in F1 families varied from additive (SR/F1-5), incomplete recessive (SR/F1-9), and incomplete dominance (SR/F1-13; Table 3). The closest to complete dominance was SR/F1-13, which was the only F1 family for which the R parent was previously crossed under greenhouse conditions $(\mathrm{R} \times \mathrm{R})$. Therefore, further inbreeding would be needed to establish families that could be used in future studies to test for allelism by crossing with other resistant populations 
TABLE 6 | Phenotypic resistance segregation observed in two pseudo- $\mathrm{F}_{2}$ and three back-cross susceptible (BC/S) families at high mesotrione dose $\left(420 \mathrm{~g}\right.$ ai ha $\left.{ }^{-1}\right)$.

\begin{tabular}{|c|c|c|c|c|c|c|c|c|}
\hline Run & Dose (g ai ha $\left.{ }^{-1}\right)$ & Family ${ }^{a}$ & Plants treated & Survivors (observed) & Survival ratio & Survivors (expected) & $x^{2}$ & $P$-value \\
\hline \multirow[t]{12}{*}{1} & 420 & $\mathrm{R}$ & 8 & 8 & 1.00 & & & \\
\hline & & S & 8 & 0 & 0.00 & & & \\
\hline & & $\mathrm{SR} / \mathrm{F} 1-8$ & 13 & 1 & 0.08 & & & \\
\hline & & SR/F1-9 & 9 & 3 & 0.33 & & & \\
\hline & & SR/F1-13 & 12 & 9 & 0.75 & & & \\
\hline & & \multicolumn{3}{|c|}{ F2 segregation } & & \multicolumn{2}{|l|}{ 1R:2F1:1S } & \\
\hline & & F2-9 & 91 & 86 & 0.95 & 37.9 & 104.6 & 0.00 \\
\hline & & $\mathrm{F} 2-13$ & 96 & 56 & 0.58 & 60.0 & 0.7 & 0.40 \\
\hline & & \multicolumn{2}{|c|}{$\mathrm{BC} / \mathrm{S}$ segregation } & & & 1F1:1S & & \\
\hline & & $\mathrm{BC}-8 / \mathrm{S}$ & 98 & 10 & 0.10 & 3.8 & 11.1 & 0.00 \\
\hline & & $B C-9 / S$ & 96 & 84 & 0.88 & 16.0 & 346.8 & 0.00 \\
\hline & & BC-13/S & 86 & 54 & 0.63 & 32.3 & 23.3 & 0.00 \\
\hline \multirow[t]{12}{*}{2} & 420 & $\mathrm{R}$ & 16 & 16 & 1.00 & & & \\
\hline & & S & 15 & 0 & 0.00 & & & \\
\hline & & $\mathrm{SR} / \mathrm{F} 1-8$ & 24 & 1 & 0.04 & & & \\
\hline & & SR/F1-9 & 9 & 4 & 0.44 & & & \\
\hline & & $\mathrm{SR} / \mathrm{F} 1-13$ & 24 & 22 & 0.92 & & & \\
\hline & & \multicolumn{3}{|c|}{ F2 segregation } & & \multicolumn{2}{|l|}{ 1R:2F1:1S } & \\
\hline & & F2-9 & 56 & 56 & 1.00 & 26.4 & 62.8 & 0.00 \\
\hline & & $\mathrm{F} 2-13$ & 94 & 82 & 0.87 & 66.6 & 12.2 & 0.00 \\
\hline & & \multicolumn{2}{|c|}{$\mathrm{BC} / \mathrm{S}$ segregation } & & & 1F1:1S & & \\
\hline & & BC-8/S & 91 & 0 & 0.00 & 1.9 & 1.9 & 0.16 \\
\hline & & BC-9/S & 94 & 68 & 0.72 & 20.9 & 136.5 & 0.00 \\
\hline & & BC-13/S & 85 & 20 & 0.24 & 38.9 & 16.9 & 0.00 \\
\hline
\end{tabular}

Chi-square $\left(\mathrm{x}^{2}\right)$ analysis for expected plant survival assuming control for mesotrione resistance by a single major gene.

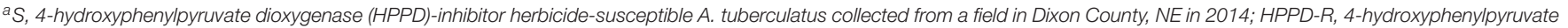
dioxygenase (HPPD)-inhibiting herbicide-resistant A. tuberculatus collected from a field in Platte County, NE in 2014. SR/F1-8 (generated BC-8/S), SR/F1-9 (generated F2-9 and BC-9/S), and SR/F1-13 (generated F2-13 and BC-13/S) are crosses originated from SxR parents made under greenhouses conditions.

and to further characterize the genotype $\times$ herbicide treatment environment.

The majority of weed species show either semi-dominance or dominance of inherited herbicide resistant alleles (Mallory-Smith et al., 1990; Lorraine-Colwill et al., 2001; Busi and Powles, 2017). For example, lack of dominance and high degree of genetic complexity within population has been documented in crosspollinated (dioecious) weed species, including Lolium rigidum, A. tuberculatus, and Alopecurus myosuroides (Petit et al., 2010; Busi et al., 2013; Huffman et al., 2015). In contrast, the majority of insecticide resistance is recessive (Sandrock and Vorburger, 2011; Shen et al., 2017; Amusa et al., 2018). In theory, insect mating $(\mathrm{S} \times \mathrm{R})$ would result in heterozygote susceptible (F1 families) phenotypes. Recessive inheritance was a key factor for the success of refugee strategy in Bt crops for delaying insecticide resistance evolution (Tabashnik et al., 2013; Jin et al., 2014). Therefore, tactics for combating herbicide resistance may be more complex than for insecticide resistance evolution. In our study, semidominance of mesotrione resistance was evident (Figures 2A,B). In such cases, theoretically, the heterozygote progeny (F1) would survive the field recommended herbicide dose (105 $\left.\mathrm{g}^{\text {ai ha }}{ }^{-1}\right)$.
Similar results from the reciprocal crosses $(S \times R$ and $\mathrm{R} \times \mathrm{S}$ ) in F1 families indicated nuclear inherited resistance alleles (Figures 2A,B). As a result, nuclear inheritance allows seed and pollen movement carrying herbicide resistance alleles (Busi et al., 2011). Pollen-mediated gene flow plays an important role in dispersing herbicide resistance traits, which was previously documented by intra- and inter-specific hybridization studies in Amaranthus species (Gaines et al., 2012; Liu et al., 2012; Sarangi et al., 2017). This result highlighted the potential gene flow for spreading the metabolism-based mesotrione resistance from this A. tuberculatus population from Nebraska, and the likelihood to increase the frequency of resistance genes within the population (Jasieniuk et al., 1996).

Herbicide resistance traits in weeds are usually nuclear inherited (Jasieniuk et al., 1996; Gaines et al., 2012). In addition, our results support the conclusion that a single major gene did not control metabolism-based resistance in this $A$. tuberculatus population from Nebraska (Tables 4-6). Regardless of the apparent heterogeneity, there was no mortality in the $\mathrm{R}$ population at the three mesotrione doses applied. In fact, the $\mathrm{R}$ population is highly resistant as $\mathrm{R}$ plants survived $420 \mathrm{~g}$ ai $\mathrm{ha}^{-1}$ of mesotrione with low injury (Figure 3E). Even with the 

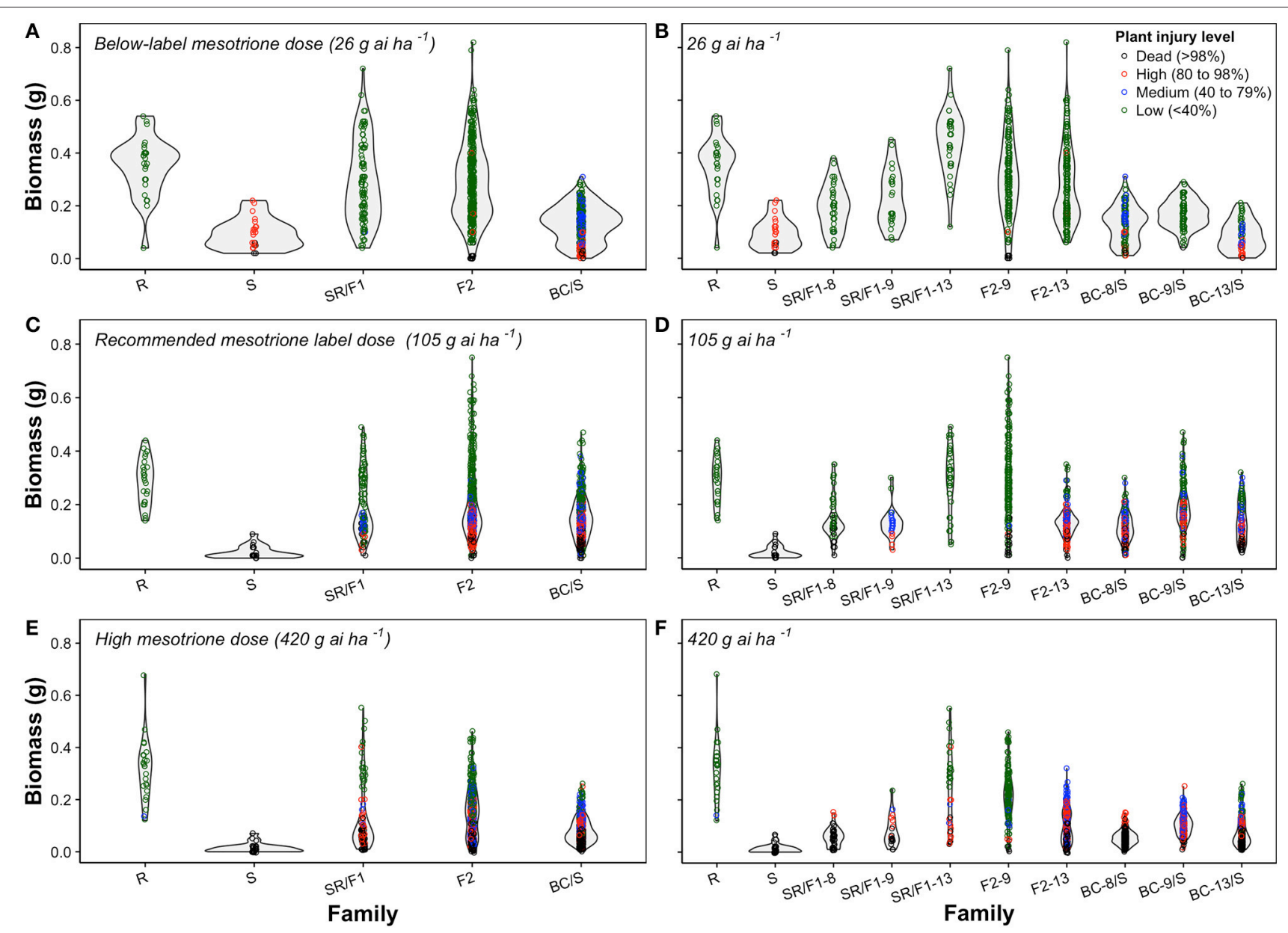

FIGURE 3 | Violin plots combining a rotated kernel density plot on each side of mesotrione inheritance of Amaranthus tuberculatus families at below-label mesotrione dose $\left(26 \mathrm{~g}_{\text {ai ha }}{ }^{-1}\right)$ of combined (A) or separated families (B); recommended mesotrione label dose (105 g ai ha ${ }^{-1}$ ) of combined (C) or separated families (D); and high mesotrione dose (420 g ai ha ${ }^{-1}$ ) of combined (E) or separated families (F). The dots represent biomass $(\mathrm{g})$ for an individual plant within a population and colors denote the mesotrione injury level in experiment conducted at the University of Nebraska-Lincoln.

apparent lack of homogeneity in the $\mathrm{R}$ parent population, the variability of the phenotype in each generated family would not be explained by a single major gene (e.g., segregation pattern of BC and F2 families; Figures 3A-F). Also, mesotrione segregation analysis in the parent ( $\mathrm{R}$ and $\mathrm{S}$ ) populations and in the $\mathrm{F} 1$, $\mathrm{F} 2$, and BC/S families showed either continuous or bell-shaped distributions for $A$. tuberculatus biomass (Figures 3A-F), which is a typical response of quantitative (polygenic) traits (Morton and MacLean, 1974; Huffman et al., 2015). Furthermore, in our study, plant mortality was lower than expected at lower doses and higher than expected at higher doses (Tables 4-6), suggesting that inheritance of mesotrione resistance alleles is additive (Tabashnik, 1991).

In weeds, herbicide metabolism-based resistance is not wellunderstood and usually conferred by multiple alleles (Délye et al., 2013). For example, polygenic resistance was reported in NTSR mechanisms of ACCase- and ALS-inhibitor herbicides in L. rigidum populations (Busi et al., 2011, 2013; Han et al., 2014) and to ACCase-inhibitors in Avena fatua (Burns et al.,
2018). However, monogenic resistance was found to endow NTSR mechanisms as well. A single major gene explained auxinic, glyphosate, and pyroxasulfone resistance in L. rigidum populations (Lorraine-Colwill et al., 2001; Busi et al., 2014; Busi and Powles, 2017) and atrazine resistance in A. tuberculatus (Huffman et al., 2015). Therefore, a single gene or multiple genes can endow NTSR mechanisms in weeds, suggesting that the number of alleles controlling NTSR varies according to the ecology and evolutionary factors contributing for weed resistance evolution. Also, these results demonstrated the complexity of NTSR mechanisms in weed species, which might be influenced by epigenetic effects (Yu and Powles, 2014; Markus et al., 2018).

Previous research in this $\mathrm{R}$ population suggested that HPPDresistance is likely due to multiple cytochrome P450 enzymes, which is also indicative of polygenic resistance (Oliveira et al., 2017b). The cytochrome P450s comprise a large plant gene family and have repeatedly been associated with metabolism-based resistance in grass weed species (Powles and Yu, 2010). Examples of metabolism-based resistance via cytochrome P450s in grass 
weed species include L. rigidum (Christopher et al., 1991; Busi et al., 2011, 2013, 2014; Han et al., 2014); A. myosuroides (Letouzé and Gasquez, 2003); and Echinochloa phyllopogon (Yun et al., 2005; Iwakami et al., 2014). In dicotyledon species, metabolismbased resistance is still under-studied (Powles and Yu, 2010). In such cases, often the presence of TSR mechanisms might mask the metabolism-based resistance (Yu and Powles, 2014). Nonetheless, metabolism-based resistance via cytochrome P450s gained attention with the evolution of 2,4 D (Figueiredo et al., 2017) and HPPD resistance (Ma et al., 2013; Kaundun et al., 2017; Nakka et al., 2017) in Amaranthus species. Multiple genes were found to confer resistance in a metabolism-based mesotrione resistant $A$. tuberculatus population from Illinois (Huffman et al., 2015). Despite different genetic background, farming system, and potentially different cytochrome P450 enzymes causing resistance, the genetics of mesotrione resistance is consistent with polygenic inheritance in the Nebraska (Oliveira et al., 2017a) and Illinois (Huffman et al., 2015) A. tuberculatus populations. Therefore, there are likely multiple genes involved in mesotrione resistant- $A$. tuberculatus populations across the north-central United States.

In summary, we confirmed that mesotrione resistance in an A. tuberculatus from Nebraska is nuclear inherited and likely mediated by multiple genes. It remains unknown if another mechanism of herbicide resistance has arisen in the $\mathrm{R}$ population from Nebraska. Other proteins play an important role in herbicide compartmentalization (transporter proteins), degradation (glutathione-S-transferases, glycosyl-transferases, esterases, hydrolases), and compensation (oxidases, peroxidases;

\section{REFERENCES}

Amusa, O. D., Ogunkanmi, L. A., Adetumbi, J. A., Akinyosoye, S. T., and Ogundipe, O. T. (2018). Genetics of bruchid (Callosobruchus maculatus Fab.) resistance in cowpea (Vigna unguiculata (L.) Walp.). J. Stored Prod. Res. 75, 18-20. doi: 10.1016/j.jspr.2017.11.004

Burns, E. E., Keith, B. K., Talbert, L. E., and Dyer, W. E. (2018). Non-target site resistance to flucarbazone, imazamethabenz and pinoxaden is controlled by three linked genes in Avena fatua. Weed Res. 58, 8-16. doi: 10.1111/wre.12279

Busi, R., Gaines, T. A., Vila-Aiub, M. M., and Powles, S. B. (2014). Inheritance of evolved resistance to a novel herbicide (pyroxasulfone). Plant Sci. 217-218, 127-134. doi: 10.1016/j.plantsci.2013.12.005

Busi, R., Neve, P., and Powles, S. (2013). Evolved polygenic herbicide resistance in Lolium rigidum by low-dose herbicide selection within standing genetic variation. Evol. Appl. 6, 231-242. doi: 10.1111/j.1752-4571.2012.00 282.x

Busi, R., and Powles, S. B. (2017). Inheritance of 2,4-D resistance traits in multiple herbicide- resistant Raphanus raphanistrum populations. Plant Sci. 257, 1-8. doi: 10.1016/j.plantsci.2017.01.003

Busi, R., Vila-Aiub, M. M., and Powles, S. B. (2011). Genetic control of a cytochrome P450 metabolism-based herbicide resistance mechanism in Lolium rigidum. Heredity 106, 817-824. doi: 10.1038/hdy.2010.124

Chatham, L. A., Wu, C., Riggins, C. W., Hager, A. G., Young, B. G., Roskamp, G. K., et al. (2015). EPSPS gene amplification is present in the majority of glyphosateresistant Illinois waterhemp (Amaranthus tuberculatus) populations. Weed Technol. 29, 48-55. doi: 10.1614/WT-D-14-00064.1

Christopher, J. T., Powles, S. B., Liljegren, D. R., and Holtum, J. A. (1991). Crossresistance to herbicides in annual ryegrass (Lolium rigidum): II. Chlorsulfuron resistance involves a wheat-like detoxification system. Plant Physiol. 95, 1036-1043. doi: 10.1104/pp.95.4.1036
Délye, 2013; Ghanizadeh and Harrington, 2017). For example, other steps in herbicide metabolism in addition to oxidation by P450s, such as initial oxidation followed by conjugation (e.g., to a sugar) may be part of a metabolic resistance mechanism. The multiple metabolic steps would be consistent with additive inheritance, due to the requirement of upregulation of more than one gene to confer high level resistance and partial resistance conferred from upregulation of only one.

\section{AUTHOR CONTRIBUTIONS}

MO and TG: designed the experiments; MO: conducted the experiments, analyzed the data, and wrote the manuscript; TG, SK, and AJ: conceptualized the research. All authors reviewed the manuscript.

\section{ACKNOWLEDGMENTS}

The authors would like to thank CAPES (Brazilian Government Foundation) Proc. $\mathrm{n}^{\circ}$ 9112-13-8 for financial support to the graduate student involved in this study. In addition, we thank Professor Don Lee for a critical review and thoughts in this manuscript draft.

\section{SUPPLEMENTARY MATERIAL}

The Supplementary Material for this article can be found online at: https://www.frontiersin.org/articles/10.3389/fpls.2018. 00060/full\#supplementary-material
Ffrench-Constant, R. H., Daborn, P. J., and Le Goff, G. (2004). The genetics and genomics of insecticide resistance. Trends Genet. 20, 163-170. doi: 10.1016/j.tig.2004.01.003

Délye, C. (2013). Unravelling the genetic bases of non-target-site-based resistance (NTSR) to herbicides: a major challenge for weed science in the forthcoming decade. Pest Manag Sci. 69, 176-187. doi: 10.1002/ps.3318

Délye, C., Jasieniuk, M., Rie, V., and Corre, L. (2013). Deciphering the evolution of herbicide resistance in weeds. Trends Genet. 29, 649-658. doi: 10.1016/j.tig.2013.06.001

Duke, S. O. (2012). Why have no new herbicide modes of action appeared in recent years? Pest Manag. Sci. 68, 505-512. doi: 10.1002/ps.2333

Figueiredo, M. R. A., Leibhart, L. J., Reicher, Z. J., Tranel, P. J., Nissen, S. J., Westra, P., et al. (2017). Metabolism of 2,4-dichlorophenoxyacetic acid contributes to resistance in a common waterhemp (Amaranthus tuberculatus) population. Pest Manag. Sci. doi: 10.1002/ps.4811. [Epub ahead of print].

Gaines, T. A., Ward, S. M., Bukun, B., Preston, C., Leach, J. E., and Westra, P. (2012). Interspecific hybridization transfers a previously unknown glyphosate resistance mechanism in Amaranthus species. Evol. Appl. 5, 29-38. doi: 10.1111/j.1752-4571.2011.00204.x

Ghanizadeh, H., and Harrington, K. C. (2017). Critical reviews in plant sciences non-target site mechanisms of resistance to herbicides non-target site mechanisms of resistance to herbicides. Crit. Rev. Plant Sci. 36, 24-34. doi: 10.1080/07352689.2017.1316134

Han, H., Yu, Q., Vila-Aiub, M., and Powles, S. B. (2014). Genetic inheritance of cytochrome P450-mediated metabolic resistance to chlorsulfuron in a multiple herbicide resistant Lolium rigidum population. Crop Prot. 65, 57-63. doi: 10.1016/j.cropro.2014.06.026

Hartzler, R. G., Battles, B. A., and Nordby, D. (2004). Effect of common waterhemp (Amaranthus rudis) emergence date on growth and fecundity in soybean. Weed Sci. 52, 242-245. doi: 10.1614/WS-03-004R 
Hausman, N. E., Singh, S., Tranel, P. J., Riechers, D. E., Kaundun, S. S., Polge, N. D., et al. (2011). Resistance to HPPD-inhibiting herbicides in a population of waterhemp (Amaranthus tuberculatus) from Illinois, United States. Pest Manag. Sci. 67, 258-261. doi: 10.1002/ps.2100

Heap, I. (2014). Global perspective of herbicide-resistant weeds. Pest Manag. Sci. 70, 1306-1315. doi: 10.1002/ps.3696

Heap, I. (2017). Herbicide Resistant Tall Waterhemp Globally. Available online at: http://www.weedscience.org/Summary/Species.aspx (Accessed August 14, 2017).

Huffman, J., Hausman, N. E., Hager, A. G., Riechers, D. E., and Tranel, P. J. (2015). Genetics and inheritance of nontarget-site resistances to atrazine and mesotrione in a waterhemp (Amaranthus tuberculatus) population from Illinois. Weed Sci. 63, 799-809. doi: 10.1614/WS-D-15-00055.1

Iwakami, S., Endo, M., Saika, H., Okuno, J., Nakamura, N., Yokoyama, M., et al. (2014). Cytochrome P450 CYP81A12 and CYP81A21 are associated with resistance to two acetolactate synthase inhibitors in Echinochloa phyllopogon. Plant Physiol. 165, 618-629. doi: 10.1104/pp.113.232843

Jasieniuk, M., Brûlé-Babel, A. L., Morrison, I. N., Brule-Babel, A. L., and Morrison, I. N. (1996). The evolution and genetics of herbicide resistance in weeds. Weed Sci. 44, 176-193. Available at: http://www.jstor.org/stable/4045802.

Jin, L., Zhang, H., Lu, Y., Yang, Y., Wu, K., Tabashnik, B. E., et al. (2014). Large-scale test of the natural refuge strategy for delaying insect resistance to transgenic Bt crops. Nat. Biotechnol. 33, 169-174. doi: 10.1038/nbt.3100

Kaundun, S. S., Hutchings, S.-J., Dale, R. P., Howell, A., Morris, J. A., Kramer, V. C., et al. (2017). Mechanism of resistance to mesotrione in an Amaranthus tuberculatus population from Nebraska, USA. PLoS ONE 12:e0180095. doi: 10.1371/journal.pone.0180095

Knezevic, S. Z., Streibig, J. C., and Ritz, C. (2007). Utilizing R software package for dose-response studies: the concept and data analysis. Weed Technol. 21, 840-848. doi: 10.1614/WT-06-161.1

Letouzé, A., and Gasquez, J. (2003). Enhanced activity of several herbicidedegrading enzymes: a suggested mechanism responsible for multiple resistance in blackgrass (Alopecurus myosuroides Huds.). Agronomie 23, 601-608. doi: 10.1051/agro:2003036

Liu, J., Davis, A. S., and Tranel, P. J. (2012). Pollen biology and dispersal dynamics in waterhemp (Amaranthus tuberculatus). Weed Sci. 60, 416-422. doi: 10.1614/WS-D-11-00201.1

Lorentz, L., Gaines, T. A., Nissen, S. J., Westra, P., Strek, H. J., Dehne, H. W., et al. (2014). Characterization of glyphosate resistance in Amaranthus tuberculatus populations. J. Agric. Food Chem. 62, 8134-8142. doi: 10.1021/jf50 $1040 \mathrm{x}$

Lorraine-Colwill, D. F., Powles, S. B., Hawkes, T. R., and Preston, C. (2001). Inheritance of evolved glyphosate resistance in Lolium rigidum (Gaud.). Theor. Appl. Genet. 102, 545-550. doi: 10.1007/s001220051680

Ma, R., Kaundun, S. S., Tranel, P. J., Riggins, C. W., McGinness, D. L., Hager, A. G., et al. (2013). Distinct detoxification mechanisms confer resistance to mesotrione and atrazine in a population of waterhemp. Plant Physiol. 163, 363-377. doi: 10.1104/pp.113.223156

Mallory-Smith, C. A., Thill, D. C., Dial, M. J., and Zemetra, R. S. (1990). Inheritance of sulfonylurea herbicide resistance in Lactuca spp. Weed Technol. 4, 787-790.

Markus, C., Pecinka, A., Karan, R., Barney, J. N., and Merotto, A. (2018). Epigenetic regulation - contribution to herbicide resistance in weeds? Pest Manag. Sci. 74, 275-281. doi: 10.1002/ps.4727

McMullan, P. M., and Green, J. M. (2011). Identification of a tall waterhemp (Amaranthus tuberculatus) biotype resistant to HPPD-inhibiting herbicides, atrazine, and thifensulfuron in Iowa. Weed Technol. 25, 514-518. doi: 10.1614/WT-D-10-00150.1

Menalled, F., Peterson, R., Smith, R., Curran, W., Páez, D., and Maxwell, B. (2016). The eco-evolutionary imperative: revisiting weed management in the midst of an herbicide resistance crisis. Sustainability 8:1297. doi: 10.3390/su8121297

Mitchell, G., Bartlett, D. W., Fraser, T. E., Hawkes, T. R., Holt, D. C., Townson, J. K., et al. (2001). Mesotrione: a new selective herbicide for use in maize. Pest Manag. Sci. 57, 120-128. doi: 10.1002/1526-4998(200102)57:2<120::AIDPS254>3.0.CO;2-E

Morton, N. E., and MacLean, C. J. (1974). Analysis of family resemblance. 3. Complex segregation of quantitative traits. Am. J. Hum. Genet. 26, 489-503.

Nakka, S., Godar, A. S., Wani, P. S., Thompson, C. R., Peterson, D. E., Roelofs, J., et al. (2017). Physiological and molecular characterization of hydroxyphenylpyruvate dioxygenase (HPPD)-inhibitor resistance in Palmer amaranth (Amaranthus palmeri S.Wats.). Front. Plant Sci. 8:555. doi: $10.3389 /$ fpls.2017.00555

Neve, P., Busi, R., Renton, M., and Vila-Aiub, M. M. (2014). Expanding the eco-evolutionary context of herbicide resistance research. Pest Manag. Sci. 70, 1385-1393. doi: 10.1002/ps.3757

Neve, P., Vila-Aiub, M., and Roux, F. (2009). Evolutionary-thinking in agricultural weed management. New Phytol. 184, 783-793. doi: 10.1111/j.1469-8137.2009.03034.x

Oliveira, M. C., Gaines, T. A., Dayan, F. E., Patterson, E. L., Jhala, A. J., and Knezevic, S. Z. (2017a). Reversing resistance to tembotrione in an Amaranthus tuberculatus (var. rudis) population from Nebraska, USA with cytochrome P450 inhibitors. Pest Manag. Sci. doi: 10.1002/ps.4697. [Epub ahead of print].

Oliveira, M. C., Jhala, A. J., Gaines, T., Irmak, S., Amundsen, K., Scott, J. E., et al. (2017b). Confirmation and control of HPPD-inhibiting herbicide-resistant waterhemp (Amaranthus tuberculatus) in Nebraska. Weed Technol. 31, 67-79. doi: $10.1017 /$ wet.2016.4

Owen, M. D. (2008). Weed species shifts in glyphosate-resistant crops. Pest Manag. Sci. 64, 377-387. doi: 10.1002/ps.1539

Patzoldt, W. L., and Tranel, P. J. (2007). Multiple ALS mutations confer herbicide resistance in waterhemp (Amaranthus tuberculatus). Weed Sci. 55, 421-428. doi: 10.1614/WS-06-213.1

Petit, C., Duhieu, B., Boucansaud, K., and Délye, C. (2010). Complex genetic control of non-target-site-based resistance to herbicides inhibiting acetylcoenzyme A carboxylase and acetolactate-synthase in Alopecurus myosuroides huds. Plant Sci. 178, 501-509. doi: 10.1016/j.plantsci.2010.03.007

Powles, S. B., and Yu, Q. (2010). Evolution in action: plants resistant to herbicides. Annu. Rev. Plant Biol. 61, 317-347. doi: 10.1146/annurev-arplant-042809-112119

Renton, M., Busi, R., Neve, P., Thornby, D., and Vila-Aiub, M. (2014). Herbicide resistance modelling: past, present and future. Pest Manag. Sci. 70, 1394-1404. doi: $10.1002 /$ ps.3773

Ritz, C., and Streibig, J. C. (2005). Bioassay analysis using R. J. Stat. Softw. 12, 1-18. doi: 10.18637/jss.v012.i05

Sandrock, C., and Vorburger, C. (2011). Single-locus recessive inheritance of asexual reproduction in a parasitoid wasp. Curr. Biol. 21, 433-437. doi: 10.1016/j.cub.2011.01.070

Sarangi, D., Tyre, A. J., Patterson, E. L., Gaines, T. A., Irmak, S., Knezevic, S. Z., et al. (2017). Pollen-mediated gene flow from glyphosate-resistant common waterhemp (Amaranthus rudis Sauer): consequences for the dispersal of resistance genes. Sci. Rep. 7:44913. doi: 10.1038/srep44913

Schultz, J. L., Chatham, L. A., Riggins, C. W., Tranel, P. J., and Bradley, K. W. (2015). Distribution of herbicide resistances and molecular mechanisms conferring resistance in Missouri waterhemp (Amaranthus rudis Sauer) populations. Weed Sci. 631, 336-345. doi: 10.1614/WS-D-14-00102.1

Shen, J., Li, D., Zhang, S., Zhu, X., Wan, H., and Li, J. (2017). Fitness and inheritance of metaflumizone resistance in Plutella xylostella. Pestic. Biochem. Physiol. 139, 53-59. doi: 10.1016/j.pestbp.2017.04.010

Stone, B. F. (1968). A formula for determining degree of dominance in cases of monofactorial inheritance of resistance to chemicals. Bull. World Health Organ. 38, 325-326

Sutton, P., Richards, C., Buren, L., and Glasgow, L. (2002). Activity of mesotrione on resistant weeds in maize. Pest Manag. Sci. 58, 981-984. doi: 10.1002/ps.554

Tabashnik, B. E. (1991). Determining the mode of inheritance of pesticide resistance with backcross experiments. J. Econ. Entomol. 84, 703-712. doi: 10.1093/jee/84.3.703

Tabashnik, B. E., Brévault, T., and Carrière, Y. (2013). Insect resistance to Bt crops: lessons from the first billion acres. 31, 510-521. doi: 10.1038/nbt.2597

Thinglum, K. A., Riggins, C. W., Davis, A. S., Bradley, K. W., AlKhatib, K., and Tranel, P. J. (2011). Wide distribution of the waterhemp (Amaranthus tuberculatus) $\triangle \mathrm{G} 210$ PPX2 mutation, which confers resistance to PPO-Inhibiting herbicides. Weed Sci. 59, 22-27. doi: 10.1614/WS-D-1000085.1

Tranel, P. J., Riggins, C. W., Bell, M. S., and Hager, A. G. (2011). Herbicide resistances in Amaranthus tuberculatus: a call for new options. J. Agric. Food Chem. 59, 5808-5812. doi: 10.1021/jf103797n

Trucco, F., Jeschke, M. R., Rayburn, A. L., and Tranel, P. J. (2005). Promiscuity in weedy amaranths: high frequency of female tall waterhemp (Amaranthus 
tuberculatus $) \times$ smooth pigweed (A. hybridus) hybridization under field conditions. Weed Sci. 53, 46-54. doi: 10.1614/WS-04-103R

Trucco, F., Tatum, T., Robertson, K. R., Lane Rayburn, A., Tranel, P. J., and Pigweed, S. F. (2006). Characterization of waterhemp (Amaranthus tuberculatus) $\times$ smooth pigweed (A. hybridus) F1 hybrids. Weed Technol. 20, 14-22. doi: 10.1614/WT-05-018R.1

Waselkov, K. E., and Olsen, K. M. (2014). Population genetics and origin of the native North American agricultural weed waterhemp (Amaranthus tuberculatus; Amaranthaceae). Am. J. Bot. 101, 1726-1736. doi: 10.3732/ajb.1400064

Wickham, H. (2009). ggplot2: Elegant Graphics for Data Analysis, 2nd Edn. New York, NY: Springer International Publishing.

Yu, Q., and Powles, S. (2014). Metabolism-based herbicide resistance and cross-resistance in crop weeds: a threat to herbicide sustainability and global crop production. Plant Physiol. 166, 1106-1118. doi: 10.1104/pp.114. 242750
Yun, M.-S., Yogo, Y., Miura, R., Yamasue, Y., and Fischer, A. J. (2005). Cytochrome P-450 monooxygenase activity in herbicide-resistant and -susceptible late watergrass (Echinochloa phyllopogon). Pestic. Biochem. Physiol. 83, 107-114. doi: 10.1016/j.pestbp.2005.04.002

Conflict of Interest Statement: The authors declare that the research was conducted in the absence of any commercial or financial relationships that could be construed as a potential conflict of interest.

Copyright $\odot 2018$ Oliveira, Gaines, Jhala and Knezevic. This is an open-access article distributed under the terms of the Creative Commons Attribution License (CC $B Y)$. The use, distribution or reproduction in other forums is permitted, provided the original author(s) and the copyright owner are credited and that the original publication in this journal is cited, in accordance with accepted academic practice. No use, distribution or reproduction is permitted which does not comply with these terms. 